https://doi.org/10.19195/0524-4544.331.18

\author{
RENATA RASZEWSKA-SKAŁECKA \\ ORCID: 0000-0001-7467-5703 \\ Uniwersytet Wrocławski \\ renata.raszewska-skalecka@uwr.edu.pl
}

\title{
Niepomijalność administracji publicznej w zakresie władztwa zakładowego - „skreślenie z listy uczniów szkoły” na kanwie orzecznictwa sądowoadministracyjnego
}

\begin{abstract}
Abstrakt: Problematyka postępowań w indywidualnych sprawach ucznia w szkole, w tym władztwa zakładowego wobec ucznia na forum szkoły, i kwestia skreślenia z listy uczniów, wpływając na status ucznia jako użytkownika zakładu administracyjnego (szkoły), jest nie tylko obecna i aktualna w nauce prawa administracyjnego, ale i ciągle potrzebuje w praktyce weryfikacji sądowej i refleksji naukowej. Postępowanie w sprawie skreślenia ucznia z listy uczniów toczy się według procedury zgodnej z przepisami postępowania administracyjnego. Skreślenie ucznia z listy uczniów szkoły następuje $\mathrm{w}$ formie decyzji administracyjnej; jest przy tym równoznaczne $\mathrm{z}$ rozwiązaniem stosunku administracyjnoprawnego, łączącego ucznia ze szkołą. Podkreślić należy, że w szkole istnieje prawny obowiązek podporządkowania się ucznia wydanym i obowiązującym na jej terenie regulacjom wewnątrzzakładowym, do których należy zwłaszcza statut szkoły. Uprawnienia zakładu administracyjnego (szkoły) wobec ucznia-użytkownika są z reguły uregulowane ustawowo, szczegółowo zaś dookreślone w statucie szkoły i regulaminach wewnątrzszkolnych. W doktrynie prawa administracyjnego przyjmuje się, że podległość ucznia jako użytkownika zakładu administracyjnego uregulowana jest w szczególności w prawie oświatowym, jego podległość zaś wszelkim aktom, poleceniom organów szkoły — określona jest jako element władztwa zakładowego. Stąd właśnie obecność i niepomijalność w szkole prawnych form działania administracji publicznej oraz władztwa zakładowego, mającego istotny wpływ na sytuację prawną ucznia w szkole. Prawo administracyjne pozwala przyjrzeć się ochronie administrowanego ucznia w szkole, a sądownictwo administracyjne - ochronie praw podmiotowych jednostki jako ucznia szkoły w państwie prawa.
\end{abstract}

Słowa kluczowe: prawo do nauki, obowiązek szkolny i obowiązek nauki, prawo oświatowe, zakład administracyjny, władztwo zakładowe, statut szkoły, skreślenie ucznia z listy uczniów. 


\section{Wprowadzenie}

Przedmiotowe rozważania prowadzone w kontekście skreślenia ucznia z listy uczniów szkoły wymagają osadzenia badanej problematyki w ujęciu prawa administracyjnego i niepomijalności administracji publicznej. Co znamienne, w państwie prawnym nie można mówić o administracji publicznej bez prawa administracyjnego ${ }^{1}$. Prawo wytycza nie tylko granice jej wyodrębnienia, ale także reguluje jej aktywność prawotwórczą, której przykładem jest administracja oświatowa i prawotwórcza działalność zakładu administracyjnego (szkoły). Wielość odesłań ustawowych do aktów prawa zakładowego, jak i obszar regulacji tymi źródłami prawa stanowi o prawnej samodzielności działalności prawotwórczej zakładu administracyjnego ${ }^{2}$. Niewątpliwie statuty i regulaminy zakładów administracyjnych są źródłami prawa ${ }^{3}$ i jako akty normatywne prawa zakładowego są prawem tworzonym dla tych wszystkich, którzy znajdują się w określonych przez nie sytuacjach. $Z$ jednej strony dotyczą aspektu ustrojowo-prawnego administracji publicznej, z drugiej zaś — praw i obowiązków jednostki/użytkownika, który korzysta ze świadczeń zakładu administracyjnego. W konsekwencji akty prawa zakładowego dookreślają zakres dozwolonej prawem samodzielności prawotwórczej zakładu i mają istotne znaczenie w określeniu zależności zakładowej i sytuacji prawnej użytkownika zakładu 4 .

Szkoły i placówki oświatowo-wychowawcze w dziedzinie oświaty i nauki są w teorii prawa administracyjnego zaliczane do zakładów administracyjnych i działają $\mathrm{W}$ zakresie wyznaczonym przepisami prawa administracyjnego ${ }^{5} . \mathrm{Na}$

1 Zob. J. Jendrośka, Narzędzia badania prawa administracyjnego, „Przegląd Prawa i Administracji" 50, 2002, s. 149; A. Błaś, Między swoboda i prawnym związaniem administracji publicznej, „Prawo” 266. Administracja publiczna w państwie prawa. Ksiegga jubileuszowa dla Profesora Jana Jendrośki, 1999, s. 23 n.

${ }^{2}$ R. Raszewska-Skałecka, Zakres prawnej samodzielności prawotwórczej zakładu administracyjnego, [w:] Administracja publiczna pod rzadami prawa. Księga pamiątkowa z okazji 70-lecia urodzin prof. zw. dra hab. Adama Btasia, red. J. Korczak, Wrocław 2016, s. 409-426.

3 R. Raszewska-Skałecka, Statut i regulamin zakładu administracyjnego jako źródła prawa, Wrocław 2007, s. 302 n.; eadem, Statut i regulamin szkolnego zaktadu administracyjnego w świetle obowiązującego systemu źródet prawa, [w:] Nowe prawo o szkolnictwie wyższym a podmiotowość studenta, red. A. Szadok-Bratuń, Wrocław 2007, s. 37-53; eadem, Miejsce statutu i regulaminu zaktadu administracyjnego w systemie źródet prawa. Kwestie wybrane, „Przegląd Prawa i Administracji” 77, 2008, s. 259-291; eadem, Zakres prawnej samodzielności..., s. 410; por. P. Chmielnicki, Zakłady administracyjne w Polsce. Ustrój wewnętrzny, Warszawa 2008, s. 96.

${ }^{4}$ P. Chmielnicki, op. cit., s. 94-95; P. Przybysz, Sytuacja prawna jednostki w zaktadzie oświatowym, [w:] Jednostka wobec dziatań administracji publicznej. Międzynarodowa Konferencja Naukowa, Olszanica 21-23 maja 2001 r., red. E. Ura, Rzeszów 2001, s. 365-379.

${ }^{5} \mathrm{~W}$ literaturze prawniczej problematykę zakładów administracyjnych na grunt zakładów oświatowych przenosi J. Homplewicz, Polskie prawo szkolne. Zagadnienia podstawowe, Warszawa 1984, s. 162 n. Wszystkie szkoły i placówki oświatowe, według autora, są zakładami w rozumieniu prawa - ibidem, s. 173; idem, Tradycyjne a wspótczesne instytucje prawa szkolnego. (Studium 
gruncie prawa szkolnego, dla całościowo pojętej myśli administratywistycznej, J. Homplewicz stwierdza:

Zakłady tworzą bowiem z istoty rzeczy kategorię jednostek powołanych do służenia określonej grupie swych „użytkowników” (destynatariuszy), tylko w zakładach występuje pewna kategoria stosunków administracyjnoprawnych, nazwanych jako „stosunki zakładowe” oparte na władztwie zakładowym oraz na formach prawnego korzystania z zakładu ${ }^{6}$.

Wypada jednak podkreślić, że samo pojęcie zakładu administracyjnego jest określeniem nie ustawodawcy, ale właśnie nauki prawa ${ }^{7}$. Nieodosobniony w swoich poglądach jest też J. Borkowski, piszący:

W pojęciu zakładu administracyjnego mieszczą się trzy elementy: użytkownicy, pracownicy oraz wyodrębniony zespół środków rzeczowych. Organ zakładu jest tym podmiotem, który będzie mógł oddziaływać swymi czynnościami na wszystkie wymienione elementy. Upoważnienie do podejmowania czynności w tych trzech grupach spraw stanowi podstawowy zakres kompetencji. Organ zakładu może być jednak wyposażony również w upoważnienie do podejmowania czynności skierowanych na zewnątrz, wykraczających poza oddziaływanie na wyżej wymienione trzy elementy, czyli może spełniać równolegle funkcje organu zakładu administracyjnego oraz organu administracji państwowej w określonej dziedzinie spraw ${ }^{8}$.

Z zakładem administracyjnym wiąże się władztwo zakładowe wobec użytkowników. Tak więc — według J. Homplewicza — „sposób korzystania z takiego zakładu jest publiczno-prawny, oparty na stosunku administracyjno-prawnym i na owym władztwie zakładowym, a nie na cywilno-prawnej umowie usługi czy użytkowania [...]"9. Z kolei zakładowe stosunki prawne, powstające pomiędzy zakła-

z zakresu nauki prawa administracyjnego), „Zeszyty Naukowe Uniwersytetu Jagiellońskiego. Prace Prawnicze" 1985, z. 112, s. 34 n.

6 J. Homplewicz, Tradycyjne a wspótczesne instytucje..., s. 35.

7 Dorobek polskiej nauki prawa administracyjnego w problematyce zakładów administracyjnych prezentują między innymi następujące opracowania, w tym o charakterze monograficznym, które dotyczą też prawa szkolnego w jego prawniczym wątku problemowym: T. Bigo, Zwiazki publiczno-prawne $w$ świetle ustawodawstwa polskiego, Warszawa 1928, s. 182-213; W. Klonowiecki, Zakład publiczny w prawie polskim. Studium prawno-administracyjne, Lublin 1933, s. 230; J.S. Langrod, Z zagadnień prawa zakładowego, „Gazeta Administracji” 1947, nr 5-6; J. Starościak, Studia z teorii prawa administracyjnego, Warszawa 1967, s. 114-136; E. Ochendowski, Zakład administracyjny jako podmiot administracji państwowej, Poznań 1969, s. 353; M. Elżanowski, Zakład państwowy w polskim prawie administracyjnym, Warszawa 1970, s. 209; J. Homplewicz, Polskie prawo...; idem, Tradycyjne a współczesne instytucje...; P. Lisowski, Szkoła samorzadowa jako zakład administracyjny, Wrocław 1997 (niepubl.); R. Raszewska-Skałecka, Statut i regulamin zakładu administracyjnego...; P. Chmielnicki, op. cit.; H. Spasowska-Czarny, Administracyjnoprawny status zakładów publicznych, Lublin 2014.

8 J. Borkowski, Organizacja zarządzania szkoła wyższa, Wrocław 1978, s. 167-168. Por. M. Elżanowski, op. cit., s. 119; J. Starościak, op. cit., s. 120.

9 J. Homplewicz, Polskie prawo..., s. 162-163; idem, Tradycyjne a wspótczesne instytucje..., s. 25. W literaturze współczesnej na ten temat piszą między innymi P. Lisowski, op. cit.; idem, Relacje strukturalne w polskim samorzadzie terytorialnym, Wrocław 2013, s. 176 n.; R. Raszewska-Skałecka, Statut i regulamin zakładu administracyjnego..., s. 39 n.; eadem, Koncepcja zaktadu administracyjnego w polskiej nauce prawa administracyjnego, „Przegląd Prawa i Administracji” 68, 
dem a jego użytkownikiem na tle korzystania z takiego zakładu, są kształtowane w ramach całego systemu obowiązującego prawa, zwłaszcza z przepisów prawa administracyjnego i wynikających z aktów prawa zakładowego ${ }^{10}$. To otwiera drogę do stwierdzenia, że

w prawie szkolnym ów użytkownik zakładu (uczeń) uzyskuje swą własną pozycję prawną w stosunkach z organami szkoły. Zadaniem szkoły zaczyna być nawet nie tyle sprawowanie władztwa wobec ucznia, ile realizacja obowiązujących przepisów szkolnych poprzez nawiązywanie owych stosunków szkolnoprawnych z uczniem jako ich podmiotem, choć tym samym i użytkownikiem zakładu ${ }^{11}$.

Pozycja prawna użytkownika zakładu od dawna była i ciągle pozostaje podstawowym kryterium problemów i stosunków zakładowych, zwłaszcza zaś kwestia skreślenia ucznia z listy uczniów czy skreślenia z listy studentów, podnoszona niejednokrotnie w orzecznictwie sądowym ${ }^{12}$. Przyjąć należy, że prawo zakładowe to zespół norm prawnych regulujących zasadniczą (docelową) część stosunków prawnych z udziałem zakładu administracyjnego, ustanowionych na obszarze tego zakładu. Prawo zakładowe to „nieodzowny element administracji publicznej w ujęciu przedmiotowym"13.

\section{Zakład administracyjny wobec użytkownika zakładu na forum szkoły}

Spróbujmy bliżej przyjrzeć się pozycji prawnej użytkownika zakładu oświatowego, a także pozycji szkoły w ujęciu prawnego charakteru jej działań, prawnym formom i skutkom jej działania oraz sposobu jej podporządkowania wła-

2005, s. 181-225; P. Chmielnicki, op. cit., s. 42-70; Z. Czarnik, J. Posłuszny, Zakład publiczny, [w:] System Prawa Administracyjnego, t. 6. Podmioty administrujace, red. R. Hauser, Z. Niewiadomski, A. Wróbel, Warszawa 2011, s. 440-458.

10 Zob. P. Lisowski, Z problematyki postępowania administracyjnego na forum szkoły samorządowej, [w:] Nauka administracji wobec wyzwań wspótczesnego państwa prawa. Międzynarodowa Konferencja Naukowa Cisna 2-4 czerwca 2002 r., red. A. Łukasiewicz, Rzeszów 2002, s. 338. Autor przez ,prawo zakładowe” rozumie ,zbiór norm prawnych obowiązujących w stosunkach z zakładem administracyjnym, ustanowionych na forum tego zakładu" - ibidem, s. 338; idem, Prawo zakładowe — in rebus angustis? (wybrane problemy administracyjnoprawne), „Przegląd Prawa i Administracji” 100, 2015, cz. 1, s. 207-219. Cechą charakterystyczną norm prawa zakładowego, jak konstatuje autor, jest to, że „obowiązują tylko w relacjach z danym zakładem administracyjnym i — nie będąc normami powszechnie obowiązującymi - są normami wewnętrznego obowiązywania (w stosunku do użytkowników zakładu — np. regulamin studiów) lub normami o charakterze powszechnie obowiązującym (względem osób aplikujących do przyjęcia w poczet destynatariuszy danego zakładu — np. zasady rekrutacji na studia) czy też normami kierownictwa wewnętrznego" - ibidem, s. 209.

11 J. Homplewicz, Tradycyjne a współczesne instytucje..., s. 38.

12 Por. postanowienie NSA z dnia 23 października 1985 roku, sygn. II SA 1997/85, ONSA 1985/2/22; postanowienie NSA z dnia 25 września 1986 roku, sygn. SA/Gd 513/86, OSP 1998/4/48.

13 P. Lisowski, Prawo zaktadowe..., s. 218. 
dzom nadzorczym. Problematyka ta wymaga szerszego ujęcia w orzecznictwie sądowym i pogłębionych refleksji naukowych.

W polskiej nauce prawa administracyjnego pojęcie „zakład administracyjny”, zamiennie: „zakład publiczny” lub „zakład użyteczności publicznej”, ewoluuje na przestrzeni dziejów i czasu ${ }^{14}$. Przyczyną takiego stanu rzeczy jest z pewnością wieloznaczność pojęcia „zakład”, używanie go w języku prawniczym w różnych znaczeniach, niejednoznaczność przedstawicieli doktryny w zdefiniowaniu pojęcia, zróżnicowanie i złożoność zależności zakładowej oraz nawiązywanie zakładowych stosunków prawnych w zakładach publicznych i niepublicznych, kwestia charakteru prawnego władztwa zakładowego w różnych zakładach administracyjnych, niespójna i zmienna regulacja prawna określająca status prawny zakładów administracyjnych (publicznych). Nie ma w polskim systemie prawnym ogólnej ustawy, która dotyczyłaby wszystkich zakładów. Trudno nie zgodzić się z J. Bociem, że dochodzą tu też — jak pisze — „okoliczności dodatkowe, wyznaczone $\mathrm{z}$ jednej strony rodzajowym poszerzeniem podmiotów świadczących usługi niematerialne (szkoły mogą być publiczne i niepubliczne), z drugiej zaś pogorszeniem sytuacji finansowej państwa (samorządów) osłabiającej i realizację gwarantowanych uprawnień obywateli" 15 .

Warto zaznaczyć, że przedstawiciele nauki prawa, chociaż różnie definiują „zakład administracyjny (publiczny)”, to jednak ich definicje są zbieżne i zwracają uwagę na podobne materie spraw. Według E. Ochendowskiego „zakład publiczny jest jednością osób i rzeczy, powołaną przez organy administracji publicznej bądź za ich zezwoleniem przez inne podmioty dla trwałej realizacji określonego celu"16. Przywrócenie i nawiązanie do określenia „zakład publiczny” autor argumentuje zwróceniem uwagi na podmioty upoważnione do tworzenia zakładów publicznych oraz do wpływania na ich działalność. Współcześnie podmiotami tymi nie są wyłącznie organy państwowe, lecz także jednostki samorządu terytorialnego, inne korporacje prawa publicznego, a nawet inne osoby prawne oraz osoby fizyczne ${ }^{17}$. Za używaniem pojęcia ,zakład publiczny” opowiada się też J. Zimmermann, zauważając, że: „zakłady zwane dawniej administracyjnymi

14 We współczesnej doktrynie prawa administracyjnego piszą o tym między innymi Prawo administracyjne, red. J. Boć, Wrocław 2007, s. 161-165; P. Lisowski, Szkoła samorzadowa...; R. Raszewska-Skałecka, Statut i regulamin zakładu administracyjnego...; P. Chmielnicki, op. cit., s. 42-70; Z. Czarnik, J. Posłuszny, op. cit., s. 440-458; P. Lisowski, Relacje strukturalne..., s. 176177; E. Ura, Prawo administracyjne, Warszawa 2015, s. 236-239; J. Zimmermann, Prawo administracyjne, Warszawa 2018, s. 199-200; M. Wierzbowski, A. Wiktorowska, Zakład administracyjny, [w:] Prawo administracyjne, red. J. Jagielski, M. Wierzbowski, Warszawa 2019, s. 174-176.

15 Prawo administracyjne..., s. 164.

16 E. Ochendowski, Pojęcie zakładu publicznego, „Studia Iuridica” 32. Współczesne problemy administracji publicznej. Księga poświęcona pamięci Profesora Marka Elżanowskiego, 1996, s. 205.

17 E. Ochendowski, Pojęcie zaktadu..., s. 203-204; por. S. Fundowicz, Decentralizacja administracji publicznej w Polsce, Lublin 2005, s. 245. 
były jednostkami państwowymi”. Autor ten proponuje nazwę ,zakład publiczny”, uzasadniając, że: „w dzisiejszym stanie prawnym zakłady mogą być prowadzone przez samorząd terytorialny lub inne podmioty pozapaństwowe" ${ }^{18}$. Jan Zimmermann przyjmuje, że

zakładem publicznym jest wyodrębniona jednostka organizacyjna otrzymująca do wykonania określony zestaw zadań publicznych od podmiotu administracji publicznej, który ją tworzy, i pozostająca z tego powodu pod stałym wpływem (nadzorem) tego podmiotu. Zakłady, nie będąc organami administracji publicznej, realizują zadania administracji, zwłaszcza w szeroko rozumianym zakresie usług niematerialnych mających szczególne znaczenie społeczne w takich dziedzinach jak oświata, $[\ldots]$. Organy tych zakładów są organami administrującymi pełniącymi typową funkcję tzw. administracji świadczącej ${ }^{19}$.

Akcentując podmiotowy charakter relacji powstającej w związku z wykonywaniem zadań publicznych z zakresu administracji świadczącej, a samą definicję zbliżając do przedmiotowego rozumienia administracji jako pewnego rodzaju działalności organizacyjnej państwa, proponuje się w doktrynie zakładem publicznym nazywać „,stosunek prawny, którego przedmiot obejmuje zadania publiczne z zakresu administracji świadczącej, realizowany w określonej strukturze prawnej, z wykorzystaniem władczych form działania prowadzących do powstania swoistych stosunków administracyjnoprawnych (zakładowych)"20.

P. Lisowski z kolei opowiada się za używaniem terminu ,zakład administracyjny”, a nie „zakład publiczny”. Jego zdaniem termin „zakład administracyjny”

wskazuje na stricte administracyjne antecedencje zakładowego funkcjonowania. [...] sygnalizuje się już na płaszczyźnie terminologicznej ów docelowo administracyjny charakter zakładów. [...] Proponowana konwencja terminologiczna nie gubi więc, lecz podkreśla związek między formą a treścią. [...] Nie bez znaczenia jest przy tym to, że w aktualnym stanie normatywnym zwrot „publiczny” bywa czasami wykorzystywany do kategoryzowania zakładów. [...] Zaniechanie z korzystania ze zwrotu ,publiczny” na poziomie zakładu jako kategorii pojęciowej jest zatem prawnie wymuszoną koniecznością. Poza tym umożliwia wykorzystanie tego kwalifikatora na niższym wewnątrzzakładowym - poziomie klasyfikacji ${ }^{21}$.

W wywodzie doktrynalnym, według autora, zakładem administracyjnym jest jednostka organizacyjna zorientowana na świadczenie — w warunkach stosunku zależności zakładowej — usług niematerialnych z zakresu administracji publicznej, której związkiem macierzystym jest przeważnie podmiot administracji publicznej, wykazująca (prawnie sankcjonowaną) tendencję do zdecentralizowanego prowadzenia działalności podstawowej ${ }^{22}$.

Zdaniem J. Bocia zakładem administracyjnym jest ,jednostka organizacyjna powołana do świadczenia usług niematerialnych na podstawie nawiązanego z użytkownikiem stosunku administracyjnoprawnego", podkreślając przy tym ce-

\footnotetext{
18 J. Zimmermann, op. cit., s. 204.

19 Ibidem.

20 Z. Czarnik, J. Posłuszny, op. cit., s. 455.

21 P. Lisowski, Szkoła samorzadowa..., s. 137-138, 151; idem, Prawo zaktadowe..., s. 208.

22 P. Lisowski, Prawo zaktadowe..., s. 208; idem, Relacje strukturalne..., s. 177.
} 
chę usług (niematerialne), fakt regulacji ustawowej i administracyjny reżim świadczeń, niezależnie od charakteru podmiotu realizującego to świadczenie ${ }^{23}$. W ocenie S. Fundowicza zakład jest utworzony przez normy prawa publicznego i przez te normy określony podmiot zobowiązań i uprawnień szczególnego rodzaju ${ }^{24}$. Podejmując próbę podsumowania stanowisk nauki, należy przyznać rację P. Chmielnickiemu, który nie decyduje się na ponowne stworzenie — jak pisze — ,jeszcze jednej — siłą rzeczy niewiele różniącej się od już istniejących — definicji” ${ }^{25}$. Poruszana kwestia jest niebagatelna; chodzi o prawem statuowaną sytuację prawną jednostki/obywatela korzystającego z usług danego zakładu administracyjnego. Dodać należy w tym miejscu, że stosunek prawny łączący organy zakładu i jego użytkowników nawiązuje się z mocy prawa (szkoła podstawowa), z mocy decyzji administracyjnej (szkoła wyższa) bądź na mocy orzeczenia sądu (zakład karny). Stosunek ten ma charakter administracyjnoprawny; jego cechą jest nadrzędność organów zakładu wobec destynatariuszy, określana mianem władztwa zakładowego ${ }^{26}$.

Prawo zakładowe należy rozumieć jako zbiór norm prawnych zawartych zwłaszcza w aktach prawa zakładowego, to jest statucie szkoły i regulaminach zakładowych, obowiązujących w stosunkach prawnych użytkownika zakładu z zakładami administracyjnymi ( $\mathrm{w}$ istocie - w stosunkach prawnych $\mathrm{z}$ danym zakładem administracyjnym). W literaturze przedmiotu P. Lisowski pisze: „klasyczną część prawa zakładowego stanowią normy prawne ustanawiane na forum tych podmiotów administracji publicznej (w szczególności przez ich organy)". Autor proponuje także przyjąć określenie „prawo dotyczące zakładów administracyjnych" ${ }^{27}$. W zakresie dorobku doktryny i poglądów judykatury należy jednak pozostać przy określeniu ,prawo zakładowe”, wykazując, że w państwie prawa ma ono pochodzenie ustawowe i nie jest jakimś rodzajem prawa pozakonstytucyjnego. Co istotne, podstawowymi formami tego prawa na forum zakładu są statut i regulaminy zakładu, stanowiąc akty normatywne prawa zakładowego ${ }^{28}$. Podkreślić należy raz jeszcze, że statut zakładu administracyjnego określa ustrój i organizację zakładu administracyjnego, kompetencje organów tego zakładu, sposób funkcjonowania i zależności organizacyjne w zakładzie. Statut uchwalany jest przez odpowiedni organ zakładu (szkoła publiczna) ${ }^{29}$ albo nadawany przez pod-

23 Prawo administracyjne..., s. 165, 164.

24 S. Fundowicz, op. cit., s. 39.

25 P. Chmielnicki, op. cit., s. 58.

${ }^{26}$ Zob. Prawo administracyjne. Pojęcia, instytucje, zasady $w$ teorii $i$ orzecznictwie, red. M. Stahl, Warszawa 2002, s. 201.

27 P. Lisowski, Prawo zaktadowe..., s. 209.

28 R. Raszewska-Skałecka, Statut i regulamin zaktadu administracyjnego...

${ }^{29}$ Zgodnie z art. 72 ust. 1 u.p.o. „Rada pedagogiczna przygotowuje projekt statutu szkoły lub placówki albo jego zmian i przedstawia do uchwalenia radzie szkoły lub placówki”. Rada szkoły lub placówki, w myśl art. 80 ust. 1 pkt 1 u.p.o., „uczestniczy w rozwiązywaniu spraw wewnętrznych szkoły lub placówki, a także: uchwala statut szkoły lub placówki”. Szerzej zob. A. Piszko, Zasady techniki prawodawczej obowiązujące przy opracowywaniu statutu szkoły, przedszkola, jednostki 
miot tworzący dany zakład (szkoła samorządowa) ${ }^{30}$ czy osobę prowadzącą szkołę niepubliczną nadającą statut ${ }^{31}$. Regulamin jako akt prawa zakładowego określa z kolei prawa i obowiązki użytkowników zakładów oraz sposób korzystania z tych praw i sposób wypełniania obowiązków (regulamin studiów). W wypadku szkoły to jej statut reguluje prawa i obowiązki uczniów w tych przypadkach, w których uczeń może zostać skreślony z listy uczniów, a także tryb składania skarg w przypadku naruszenia praw ucznia (art. 98 ust. 1 pkt 17 u.p.o.). Statut szkoły, ze względu na jego rangę prawną w szkole, określa się mianem szkolnej konstytucji ${ }^{32}$. Jednakże, na kanwie wyroku WSA w Lublinie z dnia 24 maja 2016 roku (sygn. II SA/Lu 278/16) ${ }^{33}$, przyjmuje się, że statut szkoły nie jest aktem prawa miejscowego, lecz zakładowego (wewnętrznego). Jednym z argumentów za przyjęciem takiego rozumowania jest przyjęty w wyroku sposób zmiany statutu szkoły. W nauce prawa uznaje się

prawny charakter układu zakład-destynatariusz. Podnosi się jednakże również elementy swoiste będące konsekwencją wewnętrznego charakteru powiązań między administracją a administrowanymi. Nie można jednak uznać, by z tego powodu prawo zakładowe było w całości prawem wewnętrznym w takim samym znaczeniu, jakie ustalono dla aktów normatywnych kierownictwa wewnętrznego. [...] nie można zaakceptować przede wszystkim dla tej części norm tworzonych w zakładach, które traktują o kwestiach materialnych i procesowych bezpośrednio dotyczących administrowanych. $\mathrm{W}$ takiej sytuacji mamy w istocie do czynienia $\mathrm{z}$ wejściem w materie, $\mathrm{w}$ zasadzie zastrzeżone dla norm powszechnie obowiązującego prawa ${ }^{34}$.

W tym kontekście P. Lisowski proponuje wyróżnić prawo zakładowe sensu largo i prawo zakładowe sensu stricto. Zaproponowanie takiego rodzaju podziału wynika zdaniem autora $\mathrm{z}$ tego,

czy unormowania pochodzą in concreto od organu zakładu administracyjnego (np. senatu uczelni, rady pedagogicznej) i wówczas mamy do czynienia z prawem zakładowym w ścisłym znaczeniu, czy też zostały ustanowione przez organ podmiotu macierzystego (organu prowadzącego dany zakład administracyjny) — co odpowiada charakterystyce prawa zakładowego sensu largo. [...]

oświatowej, https://sip.lex.pl/\#/publication/470087419/piszko-agata-zasady-techniki-prawodawczejobowiazujace-przy-opracowywaniu-statutu-szkoly...?cm=URELATIONS (dostęp: 20.10.2019).

30 Pierwszy statut nadaje szkole organ prowadzący lub osoba prowadząca — w przypadku szkół prowadzonych przez osoby fizyczne lub osoby prawne niebędące jednostkami samorządu terytorialnego. Zgodnie z art. 88 ust. 7 u.p.o. organ lub osoba, o których mowa w art. 8 ust. 2, zakładająca szkołę lub placówkę podpisuje akt założycielski oraz nadaje pierwszy statut. „Akt założycielski i statut szkoły lub placówki publicznej przesyła się właściwemu kuratorowi oświaty oraz innym organom właściwym do sprawowania nadzoru pedagogicznego nad szkołą lub placówką" — art. 88 ust. 8 u.p.o.

31 Zgodnie z art. 172 ust. 1 u.p.o., ,,szkoła lub placówka działa na podstawie statutu nadanego przez osobę prowadzącą".

32 Zob. A.J. Jeżowski, Statut konstytucja szkoty, Sopot-Wrocław 2017; idem, Statut szkoty (od) nowa, „Dyrektor Szkoły” 2017, nr 8, s. 28-32.

33 LEX nr 2075221. Zob. A. Piszko, op. cit.

34 P. Lisowski, Akty normatywne stanowione przez organy zakładów administracyjnych (prawo zaktadowe), [w:] Prawo administracyjne, red. J. Boć, s. 101. 
w obu przypadkach mamy do czynienia $\mathrm{z}$ formami działania administracji publicznej w typie aktów normatywnych ${ }^{35}$.

Pozycja prawna użytkownika zakładu oświatowego w szkole jest kształtowana $\mathrm{w}$ ramach całego obowiązującego systemu prawa, zwłaszcza zaś prawa administracyjnego. Między zakładem a jego użytkownikiem nawiązuje się stosunek administracyjnoprawny w zakresie jego podstawowej działalności. Dodajmy, że

nawet w sytuacji, gdy za określone usługi użytkownik musi ponosić opłaty, mają one charakter świadczenia administracyjnego (należności administracyjnej), a nie zapłaty (świadczenia w sensie cywilnoprawnym). Między stronami wytwarza się też stosunek władztwa zakładowego. [...] Sferę stosowania środków administracyjnoprawnych przez organy zakładu ustala akt prawny o utworzeniu zakładu, sprecyzowane zaś zostają one w regulaminie lub statucie danego zakładu ${ }^{36}$.

W nauce prawa podkreśla się, że kwestia pewności prawa w procesach stanowienia i stosowania prawa, w tym zwłaszcza prawa administracyjnego, istotnie wpływa na sytuację prawną jednostki ${ }^{37}$. To właśnie ta gałąź prawa, jak zauważa Z. Duniewska, zrodziła się z potrzeby ochrony administrowanych ${ }^{38}$. Złożoność zagadnienia pewności prawa, jak stwierdza autorka, „nabiera znaczenia w sytuacji prawnej określonego podmiotu w połączeniu z wyznaczającą ją decyzją tworzenia lub stosowania prawa" ${ }^{39}$. W literaturze przedmiotu trafnie podkreśla się, że „podstawowym założeniem właściwym dla państwa prawnego jest ochrona praw podmiotowych jednostki" ${ }^{40}$. Ma ono utwierdzać w przeświadczeniu, że pewność prawa $\mathrm{w}$ państwie prawa koresponduje $\mathrm{z}$ konstytucyjnymi zasadami odnoszonymi do zasad prawa administracyjnego i administracji publicznej, zwłaszcza z zagwarantowaniem „bezpieczeństwa prawnego”, zaufaniem obywatela do państwa, „przewidywalnością prawa”, konstytucyjną i doktrynalną „zasadą pewności prawa”, ,uzasadnionymi (usprawiedliwionymi) oczekiwaniami”41. W pełni uzasadnione jest stwierdzenie, że

35 P. Lisowski, Prawo zaktadowe..., s. 209-210.

36 E. Ura, op. cit., s. 237, 239.

37 Dla przykładu zob. rozważania w monografiach Pewność sytuacji prawnej jednostki w prawie administracyjnym, red. A. Błaś, Warszawa 2012; Niepewność sytuacji prawnej jednostki w prawie administracyjnym, red. A. Błaś, Warszawa 2014.

38 Z. Duniewska, Pewność prawa administracyjnego a sytuacja prawna jednostki - kilka refleksji, [w:] Jednostka wobec władczej ingerencji organów administracji publicznej. Księga jubileuszowa dedykowana Profesor Barbarze Adamiak, red. J. Korczak, K. Sobieralski, Wrocław 2019, s. 118.

39 Ibidem, s. 120.

40 Ibidem, s. 118, cyt. za: B. Adamiak, Wptyw koncepcji ustrojowych na instytucje procesowego prawa administracyjnego, [w:] Jednostka wobec działań administracji publicznej. Międzynarodowa Konferencja Naukowa, Olszanica, 21-23 maja 2001 r., red. E. Ura, Rzeszów 2001, s. 15; por. eadem, Administracja publiczna pod rządami prawa a rozporządzalność jednostki prawem do obrony, [w:] Administracja publiczna pod rzadami prawa. Księga pamiątkowa z okazji 70-lecia urodzin prof. zw. dra hab. Adama Błasia, red. J. Korczak, Wrocław 2016, s. 17 n.

${ }^{41}$ Zob. R. Raszewska-Skałecka, Zasady konstytucyjne a prawo administracyjne, [w:] Administracja. Prawo administracyjne. Część ogólna, red. J. Blicharz, L. Zacharko, Katowice 2018, s. 169190; Z. Duniewska, op. cit., s. 120-126. 
poddanie administracji publicznej rządom prawa wymaga budowy systemu gwarancji prawnych. [...] Jednostka w zaufaniu do organów państwa ma prawo oczekiwać, że działania te są wynikiem rządów prawa, a nie rządów bezprawia. Budowa zatem systemu gwarancji poddania administracji publicznej rządom prawa opierać powinna się na instytucjach, które mają wykluczać ich naruszenia ${ }^{42}$.

Ma to podstawowe znaczenie dla ochrony jednostki, która, jak stwierdza B. Adamiak,

jest bądź bezpośrednio, bądź pośrednio dotknięta skutkami działań administracji publicznej. Bezpośrednio, gdy działania wprost kształtują jej uprawnienia lub obowiązki przez działania władcze w formie decyzji administracyjnej, czy aktów prawa miejscowego. [...] pośrednio wpływają na sytuację jednostki, [...] gdy skutki prawne nie ograniczają się wyłącznie do jednostki nabywającej uprawnienie, ale też na interesy faktyczne innych podmiotów ${ }^{43}$.

W doktrynie procesowego prawa administracyjnego przyjmuje się, że jego podstawową funkcją jest „ochrona praw jednostki wobec ingerencji w jej sytuację prawną przez organy administracji publicznej” ${ }^{44}$. Istotną rolę w zakresie ochrony jednostki, jak słusznie zauważa Z. Duniewska, ,pełni też prawo materialne i ustrojowe”, które — według B. Adamiak — „nie może tworzyć wartości sprzecznych dla praw jednostki i pełnych gwarancji ich ochrony" ${ }^{\prime 5}$. Trudno nie zgodzić się z tym, że

zasada pewności prawa wymaga, by akt prawny był jasny, precyzyjny oraz przewidywalny co do skutków prawnych. Pewność prawa jest fundamentalną wartością leżącą u podstaw prawa w demokratycznym państwie prawnym. Pewność prawa jest wartością samą w sobie, która dodatkowo wspiera i umacnia inne wartości ${ }^{46}$.

\section{Władztwo zakładowe w judykaturze „skreślenie ucznia z listy uczniów”}

Przegląd niektórych opinii naukowych i judykatury potwierdza, że doświadczenie prawne przywiązuje istotną wagę do roli orzecznictwa sądowego w stosunku do zakładów administracyjnych, jakimi są szkoły i placówki oświatowo-wychowawcze. Odnośny wpływ obejmuje tworzenie prawa zakładowego i stosowanie aktów wewnątrzzakładowych przez organy zakładu administracyjnego, wpływając jednostronnie i w sposób władczy na sytuację prawną użytkownika danego zakładu (między innymi ucznia, wychowanka, studenta) na forum szkoły. W kognicji sądów administracyjnych przyjmuje się, że

\footnotetext{
42 B. Adamiak, Administracja publiczna ..., s. 17.

43 Ibidem.

44 B. Adamiak, Wptyw koncepcji ustrojowych..., s. 20, cyt. za: Z. Duniewska, op. cit., s. 118.

45 B. Adamiak, Wplyw koncepcji ustrojowych..., s. 21.

46 Z. Duniewska, op. cit., s. 117.
} 
szkoła publiczna jest zakładem administracyjnym, a więc podmiotem składającym się z wyodrębnionego majątku oraz osób, które przy użyciu tego majątku świadczą usługi oświaty, który to zakład zostaje utworzony na podstawie ustawy w celu realizacji zadań publicznych przy wykorzystaniu tzw. władztwa zakładowego. Władztwo zakładowe nie jest samoistnym władztwem państwowym, lecz częścią tego władztwa, wynikającą z upoważnienia organów zakładu do abstrakcyjnych, jak i konkretnych regulacji na podstawie i w ramach ustaw. Istotę władztwa zakładowego stanowi więc zakres upoważnień dla organów zakładu do jednostronnego kształtowania stosunków prawnych z użytkownikami zakładu. [...] władztwo zakładowe jest częścią władztwa państwowego, przekazaną w drodze ustawy organom danego zakładu publicznego. [...] organy te są uprawnione do podejmowania konkretnych regulacji na podstawie i w ramach ustaw. [...] uregulowania zawarte w aktach wewnątrzzakładowych wiążą użytkowników zakładu, o ile są zgodne z przepisami powszechnie obowiązującymi, na podstawie których zostały podjęte (wyrok NSA z 12 czerwca 2001, I SA $2521 / 00)^{47}$. Władztwo zakładowe, jakimi dysponują szkoły publiczne, uprawnia je do kształtowania w sposób jednostronny i władczy sytuacji prawnej użytkowników, na których rzecz usługi oświatowe są świadczone ${ }^{48}$.

Na uwagę zasługuje zwłaszcza to orzecznictwo sądów administracyjnych, które wypowiada się w przedmiocie władztwa zakładowego i kompetencji organów zakładu administracyjnego. Kognicja sądów administracyjnych jest w tej materii zgodna. I tak, NSA w postanowieniu z dnia 17 listopada 2008 roku (sygn. akt I OSK 1180/08) wskazał, że dyrektor szkoły publicznej jest organem administracji szkolnej. Takie samo stanowisko zajął NSA w wyroku z dnia 25 kwietnia 2012 roku (sygn. akt I OSK 248/12), dowodząc, że dyrektor szkoły publicznej jest organem władzy publicznej. Sąd zwrócił również uwagę, że zakład administracyjny zostaje

utworzony na podstawie ustawy w celu realizacji zadań publicznych przy wykorzystaniu tzw. władztwa zakładowego. [...] uregulowania zawarte w aktach wewnątrzzakładowych wiążą użytkowników zakładu, o ile są zgodne z przepisami powszechnie obowiązującymi, na podstawie których zostały podjęte (wyrok NSA z dnia 12.06.2001 r., sygn. akt I SA 2521/00). [...] Za przyznaniem dyrektorowi szkoły publicznej statusu organu administracji publicznej przemawia przyznanie mu szeregu kompetencji ${ }^{49}$

określonych w art. 68 u.p.o., w tym władczych wobec użytkowników zakładu ${ }^{50}$. Dyrektorowi szkoły przyznano kompetencję do podejmowania działań władczych wobec uczniów, w tym do wydawania decyzji o skreśleniu ucznia z listy uczniów. Zgodnie z art. 68 ust. 2 u.p.o. „,dyrektor szkoły lub placówki może, w drodze decyzji, skreślić ucznia z listy uczniów w przypadkach określonych w statucie szkoły lub placówki. Skreślenie następuje na podstawie uchwały rady pedagogicznej, po zasięgnięciu opinii samorządu uczniowskiego". Trzeba jednak dodać za usta-

47 LEX nr 54756.

48 Wyrok NSA w Warszawie z dnia 25 kwietnia 2012 roku, sygn. I OSK 248/12, LEX nr 1264738, http://orzeczenia.nsa.gov.pl/doc/60C64AF354 (dostęp: 30.09.2019).

49 Wyrok WSA w Warszawie z dnia 13 kwietnia 2016 roku, sygn. II SAB/Wa 1069/15, LEX nr 2055148

${ }^{50}$ Ustawa z dnia 14 grudnia 2016 roku Prawo oświatowe (tekst jedn. Dz.U. z 2019 r. poz. 1148 z późn. zm.). 
wodawcą, jak wynika z art. 68 ust. 3 u.p.o., że „przepis ust. 2 nie dotyczy ucznia objętego obowiązkiem szkolnym. W uzasadnionych przypadkach uczeń ten, na wniosek dyrektora szkoły, może zostać przeniesiony przez kuratora oświaty do innej szkoły". Dodać w tym miejscu wypada, że w świetle art. 68 ust. 3a u.p.o., „W przypadku ucznia szkoły artystycznej objętego obowiązkiem szkolnym dyrektor szkoły artystycznej może skreślić ucznia z listy uczniów w trybie określonym w ust. 2, po uzyskaniu pozytywnej opinii specjalistycznej jednostki nadzoru, o której mowa w art. 53 ust. 1". Zgodnie z art. 68 ust. 4 u.p.o. dyrektor szkoły lub placówki skreśla ucznia z listy uczniów na pisemny wniosek rodziców lub pełnoletniego ucznia (art. 68 ust. 4 u.p.o.). Przepisy art. 68 ustawy Prawo oświatowe odmiennie regulują sytuację skreślenia ucznia z listy uczniów w szkołach publicznych oraz niepublicznych (art. 172 ust. 2 pkt 5 u.p.o.) ${ }^{51}$. Zgodnie z art. 172 ust. 2 pkt 5 u.p.o. statut szkoły lub placówki niepublicznej powinien określać prawa i obowiązki uczniów szkoły lub placówki, w tym przypadku, w których uczeń może zostać skreślony z listy uczniów szkoły lub placówki, a także tryb składania skarg w przypadku naruszenia praw uczniów. Są to

przypadki, w których uczeń takiej szkoły może zostać skreślony z listy uczniów, niezależnie od tego, czy podlega on obowiązkowi szkolnemu [...], bowiem [...] jedną z istotnych różnic między szkołami publicznymi i niepublicznymi jest odpłatność za nauczanie w szkole niepublicznej ${ }^{52}$.

Wskazany powyżej art. 68 ust. 3 u.p.o. odmiennie traktuje sytuację ucznia, który jest w trakcie realizacji obowiązku szkolnego od sytuacji ucznia, który już nie realizuje tego obowiązku. Zaznaczyć należy, co wynika wyraźnie z art. 35 ust. 2 u.p.o., że obowiązek szkolny dziecka rozpoczyna się z początkiem roku szkolnego w roku kalendarzowym, w którym dziecko kończy siedem lat, oraz trwa do ukończenia szkoły podstawowej, nie dłużej jednak niż do ukończenia osiemnastego roku życia.

Skreślenie ucznia z listy uczniów jest decyzją administracyjną dyrektora szkoły, poprzedzoną uchwałą rady pedagogicznej, po zasięgnięciu opinii samorządu uczniowskiego. Należy zauważyć, że dyrektor szkoły może skreślić pełnoletniego ucznia szkoły podstawowej z listy uczniów na podstawie art. 68 ust. 2 u.p.o. Co istotne:

51 Zob. wyrok WSA w Warszawie z dnia 16 listopada 2012 roku, sygn. II SA/Wa 1234/12, LEX nr 1249062, zgodnie z którym „objęty obowiązkiem szkolnym uczeń szkoły publicznej nie może być skreślony z listy uczniów, tylko może zostać przeniesiony do innej szkoły. Zasada ta nie dotyczy natomiast objętego obowiązkiem szkolnym ucznia szkoły niepublicznej, która posiada uprawnienia szkoły publicznej [...]”. Dodać należy, że szkoły niepubliczne różnią się pod względem struktury organizacyjnej i systemu zarządzania od szkół publicznych. Potwierdzeniem tego stanu rzeczy jest oddzielna w ustawie regulacja (rozdział 3 dotyczący zarządzania szkołami i placówkami publicznymi i oddzielny statutu szkoły — art. 98 ust. 1 pkt 17 u.p.o., w przypadku szkół niepublicznych — rozdział 8 ,Szkoły i placówki niepubliczne” i przewiduje zwłaszcza regulację statutową (art. 172 ust. 2 u.p.o.).

52 Por. wyrok NSA z dnia 15 października 2010 roku, sygn. I OSK 1061/10; wyrok WSA w Warszawie z dnia 16 listopada 2012 roku, sygn. II SA/Wa 1234/12, LEX nr 1249062. 
skreślenie ucznia nie następuje automatycznie z uzyskaniem przez niego pełnoletności. Uczeń może być skreślony, jeśli w rażący sposób narusza zasady zapisane w statucie szkoły oraz zostały wyczerpane wszystkie możliwości oddziaływań wychowawczych. Skreślenie ucznia z listy uczniów jest decyzją administracyjną dyrektora szkoły, [...] decyzja ta powinna być wydana zgodnie z ustawą z 14.06.1960 r. — Kodeks postępowania administracyjnego, a więc zawierać m.in. uzasadnienie oraz pouczenie o trybie odwołania od decyzji. [...] dyrektor wydając decyzję, musi ją uzasadnić, np. wskazać, jakie podjęto działania mające na celu wyeliminowanie nieobecności ucznia w szkole. Powodem skreślenia ucznia może być zaprzestanie uczęszczania do szkoły przez ucznia, czyli długotrwałe nieobecności nieusprawiedliwione, które nie zostały wyeliminowane mimo podjętych przez szkołę działań. Dyrektor powinien wskazać w uzasadnieniu, jakie to były działania. Nieobecności ucznia w szkole mogą być przyczyną nieklasyfikowania ucznia, nie mogą natomiast stanowić jedynej podstawy do skreślenia ucznia z listy uczniów, chyba że są długotrwałe i powtarzające się, a podjęte przez szkołę działania nie odniosły skutku. Uczniowi od wydanej decyzji o skreśleniu z listy uczniów przysługuje odwołanie do kuratora oświaty. Skreślenie pełnoletniego ucznia szkoły podstawowej nie wymaga zgody kuratora oświaty ${ }^{53}$.

Warto przypomnieć, że ustawodawca wyklucza możliwość skreślenia ucznia objętego obowiązkiem szkolnym z listy uczniów. Zgodnie z art. 98 ust. 1 pkt 20 u.p.o. statut określa także przypadki, w których dyrektor szkoły podstawowej może wystąpić do kuratora oświaty z wnioskiem o przeniesienie ucznia do innej szkoły. Z pewnością w takiej sytuacji

to ostateczna kara, przy drastycznym zachowaniu ucznia i wyczerpaniu wszystkich wcześniejszych możliwości. Natomiast na prośbę rodziców dyrektor zawsze może przenieść ucznia do równoległego oddziału, jeżeli ma taką możliwość (np. zwiększona liczba uczniów nie wymaga zmian organizacyjnych dotyczących np. podziału na grupy $)^{54}$.

W odniesieniu do organów szkoły NSA wskazał, że dyrektor szkoły publicznej jest organem władzy publicznej realizującym zadania publiczne, związane z realizacją prawa każdego obywatela do nauki odpowiedniej do wieku i osiągniętego rozwoju, a nadto dysponuje majątkiem publicznym, jest uprawnionym do działania w formie władczej w stosunku do uczniów szkoły, na przykład poprzez wydawanie decyzji administracyjnych w przedmiocie skreślenia ucznia z listy uczniów $^{55}$. W judykaturze NSA wskazuje, że

53 B. Wojtczak, Czy skreślenie petnoletniego ucznia z listy uczniów jest decyzją administracyjna dyrektora szkoty poprzedzona uchwata rady pedagogicznej?, https://sip.lex.pl/\#/question -and-answer/621973678/czy-skreslenie-z-listy-uczniow-odbywa-sie-w-drodze-uchwaly-rady-pedagogicznej-i-jest-wymagana...?cm=URELATIONS (dostęp: 20.10.2019).

54 B. Wojtczak, Czy dyrektor szkoty może przenieść ucznia do klasy równoległej ze względu na , dobro" tego ucznia?, https://sip.lex.pl/\#/question-and-answer/621863125/czy-dyrektor-szkoly-moze-przeniesc-ucznia-do-klasy-rownoleglej-ze-wzgledu-na-dobro-tego-ucznia?cm=URELATIONS (dostęp: 20.10.2019).

55 Por. wyrok WSA w Łodzi z dnia 26 września 2014 roku, sygn. II SAB/Ed 102/14, LEX nr 1520295. „Dyrektor szkoły publicznej jest organem władzy publicznej obowiązanym do udzielania informacji publicznych, bowiem przysługuje mu władztwo zakładowe będące częścią władztwa państwowego przekazanego w drodze u.s.o" - ibidem. „Dyrektor szkoły jest uprawniony do działania w formie władczej w stosunku do uczniów, np. poprzez wydawanie decyzji administracyjnych w przedmiocie skreślenia ucznia z listy uczniów oraz realizuje zadania publiczne związa- 
władztwo zakładowe nie jest jakimś samoistnym władztwem państwowym, lecz częścią tego władztwa, wynikającą z upoważnienia organów zakładu do abstrakcyjnych, jak i konkretnych regulacji na podstawie $\mathrm{i} w$ ramach ustaw. Istotę władztwa zakładowego stanowi więc zakres upoważnień dla organów zakładu do jednostronnego kształtowania stosunków prawnych z użytkownikami zakładu [...], jak również z osobami, które znalazły się na terenie zakładu w innym charakterze [...]. W zakładzie administracyjnym proces realizacji zadań publicznych przebiega w obrębie szeroko pojętej jego organizacji. Wynika to z faktu, że grupa społeczna złożona z użytkowników zakładu administracyjnego ma zawsze (w danym przedziale czasu) charakter mniej lub bardziej zamknięty ${ }^{56}$.

W wyroku NSA z dnia 12 czerwca 2001 roku zauważa się, że korzystanie z zakładu publicznego może być dobrowolne, jak ma to miejsce na przykład w przypadku uniwersytetu, lub obowiązkowe. Przykładem obowiązkowego korzystania z zakładu jest chociażby obowiązek szkolny na przykład w przypadku szkoły publicznej — nauka jest obowiązkowa do ukończenia osiemnastego roku życia.

Przyjęcie w poczet użytkowników zakładu publicznego następuje w drodze aktu podjętego przez upoważniony organ zakładu. Akt ten może być podjęty w wyniku oświadczenia woli użytkownika (kandydata) zakładu, jak ma to np. miejsce w przypadku studenta studiów wieczorowych. Z chwilą przyjęcia danej osoby w poczet użytkowników staje się ona podmiotem praw i obowiązków, które przysługują bądź obciążają użytkowników danego zakładu. Te prawa i obowiązki wynikają zarówno z przepisów powszechnie obowiązujących (ustaw i aktów normatywnych wykonawczych), jak i ze statutów i regulaminów zakładowych. Użytkownika, który dobrowolnie przystąpił do zakładu administracyjnego (np. studenta), wiążą przepisy zawarte w aktach normatywnych wewnątrzzakładowych, ponieważ jego wniosek o przyjęcie jest równocześnie wyrażeniem zgody na poddanie się reżimowi prawnemu, obowiązującemu w danym zakładzie. [...] władztwo zakładowe jest częścią władztwa państwowego, przekazaną w drodze ustawy organom danego zakładu publicznego. [...] organy te są uprawnione do podejmowania konkretnych regulacji na podstawie $\mathrm{i} w$ ramach ustaw. Zatem uregulowania zawarte w aktach wewnątrzzakładowych wiążą użytkowników zakładu, o ile są zgodne z przepisami powszechnie obowiązującymi, na podstawie których zostały podjęte ${ }^{57}$.

Wpływ judykatury na prawo zakładowe i władztwo zakładowe od dawna jest przedmiotem zainteresowania $\mathrm{w}$ nauce prawa. W świetle poglądów judykatury

powierzenie funkcji dyrektora szkoły nie wiąże się tylko z uprawnieniami pracowniczymi, ale mieści się także w zakresie administracji publicznej. Dyrektor szkoły publicznej stanowi bowiem organ administracji szkolnej. [...] W przypadku powierzenia funkcji dyrektora szkoły publicznej akt taki poprzedzony jest aktami i czynnościami z zakresu administracji publicznej $[\ldots]^{58}$.

W orzecznictwie sądowym wskazuje się, że

ne z realizacją prawa obywatela do kształcenia się oraz prawa dzieci i młodzieży do wychowania i opieki, odpowiednich do wieku i osiągniętego rozwoju, a nadto dysponuje majątkiem publicznym", ibidem. Na przykład wyroki NSA: z dnia 25 kwietnia 2012 roku, sygn. I OSK 248/1; z dnia 9 października 2012 roku, sygn. I OSK 1755/12, LEX nr 1233168; wyrok WSA w Poznaniu z dnia 5 września 2014 roku, sygn. II SAB/Po 57/14; zob. www.orzeczenia.nsa.gov.pl (dostęp: 30.09.2019).

56 Wyrok NSA (do 2003.12.31) w Warszawie z dnia 12 czerwca 2001 roku, sygn. I SA 2521/00, LEX nr 54756.

57 LEX nr 54756; por. wyrok WSA w Warszawie z dnia 13 kwietnia 2016 roku, sygn. II SAB/ Wa 1070/15, LEX nr 2055153.

58 Postanowienie NSA z dnia 17 października 2008 roku, sygn. I OSK 1180/08, LEX nr 533158. 
istotę władztwa zakładowego stanowi zakres upoważnień dla organów zakładu do jednostronnego kształtowania stosunków prawnych z użytkownikami zakładu, jak również z osobami, które znalazły się na terenie zakładu w innym charakterze. W zakładzie administracyjnym proces realizacji zadań publicznych przebiega w obrębie szeroko pojętej jego organizacji. Wynika z faktu, że grupa społeczna złożona z użytkowników zakładu administracyjnego ma zawsze (w danym przedziale czasu) charakter mniej lub bardziej zamknięty ${ }^{59}$.

Nie ulega też wątpliwości, że organy zakładu administracyjnego podejmują wobec jego użytkowników tak zwane akty zakładowe, które mogą mieć charakter aktów zewnętrznych, jak i wewnętrznych ${ }^{60}$. Mając to na uwadze, warto zauważyć, że sprawą indywidualną użytkownika zakładu publicznego, jak wynika z orzecznictwa sądowego ${ }^{61}$, są takie sytuacje, kiedy rozstrzygnięcie organu zakładu dotyczy sfery praw i obowiązków użytkownika zakładu i — co ważne - wywiera bezpośredni skutek na zewnątrz. Kontroli sądów administracyjnych nie podlegają akty zakładowe wewnętrzne, a więc takie, które nie wywołują skutków prawnych poza obszarem działania zakładu. Do aktów zakładowych zewnętrznych orzecznictwo sądowe zalicza między innymi decyzje administracyjne o skreśleniu z listy uczniów szkoły czy skreśleniu studentów z listy uczelni, co przesądza w konsekwencji o sądowo-administracyjnej drodze zaskarżania takich decyzji. Trudno nie zgodzić się z P. Lisowskim, że

taka decyzja jest aktem administracyjnym zewnętrznym, zawiera bowiem rozstrzygnięcie w indywidualnej sprawie administrowanego, in conreto dotyczące rozwiązania stosunku zakładowego i dlatego jako akt wywołujący zmianę statusu prawnego użytkownika [...] zakładu, jest decyzją administracyjną w rozumieniu kodeksu postępowania administracyjnego ${ }^{62}$.

Bez wątpienia statut szkoły jest aktem normatywnym i, jak słusznie stwierdza A. Jeżowski,

w sposób władczy wypowiada wolę uprawnionego organu szkoły i wydany winien być z zachowaniem przepisanego trybu, a skierowany do adresatów oznaczonych generalnie (wszystkich, którzy w jakikolwiek sposób ze szkoły korzystają). Postanowienia statutu są więc prawem, którego naruszenie uzasadnia stwierdzenie jego nieważności ${ }^{63}$,

59 Wyrok WSA w Białymstoku z dnia 15 lipca 2008 roku, sygn. SA/Bk 320/08, LEX nr 566519; por. postanowienie NSA z dnia 18 września 2012 roku, sygn. I OSK 1583/12, http://www.orzeczenia-nsa.pl/postanowienie/i-osk-1583-12,sprawy_kandydatow_na_studia_i_studentow_szkolnictwo_wyzsze, 2501213.html (dostęp: 20.03.2019).

${ }^{60}$ II SA/Sz 46/16 - postanowienie WSA w Szczecinie z dnia 28 stycznia 2016 roku, sygn. II SA/Sz 46/16, http://www.orzeczenia-nsa.pl/postanowienie/ii-sa-sz-46-16/sprawy_kandydatow_na_ studia i studentow odrzucenie skargi/11a6ad3.html (dostęp: 20.03.2019).

${ }_{61}$ Zob. wyroki: NSA z dnia 12 czerwca 2001 roku, sygn. I SA 2521/00, LEX 54756; WSA z dnia 30 kwietnia 2009 roku, sygn. III SA/Lu 462/08, LEX 554846; NSA z dnia 6 sierpnia 2010 roku, sygn. I OSK 673/10), http://www.orzeczenia-nsa.pl/wyrok/i-osk-673-10,sprawy_kandydatow_na_studia_i_studentow_szkolnictwo_wyzsze,f56078.html (dostęp: 20.03.2019).

${ }^{62}$ P. Lisowski, Z problematyki postępowania administracyjnego..., s. 332-351.

63 A.J. Jeżowski, Statut szkoły..., s. 29. 
a co wynika $z$ orzecznictwa sądowoadministarcyjnego. Problemy natury prawnej związane z prawidłowym skreśleniem ucznia z listy uczniów przez dyrektora szkoły wpisane są w postępowanie administracyjne i dlatego też niejednokrotnie są weryfikowane przez sądy.

\section{Bibliografia}

Adamiak B., Administracja publiczna pod rządami prawa a rozporządzalność jednostki prawem do obrony, [w:] Administracja publiczna pod rzadami prawa. Księga pamiatkowa z okazji 70-lecia urodzin prof. zw. dra hab. Adama Błasia, red. J. Korczak, Wrocław 2016.

Adamiak B., Wpływ koncepcji ustrojowych na instytucje procesowego prawa administracyjnego, [w:] Jednostka wobec działań administracji publicznej. Międzynarodowa Konferencja Naukowa, Olszanica, 21-23 maja 2001 r., red. E. Ura, Rzeszów 2001.

Bigo T., Zwiazki publiczno-prawne w świetle ustawodawstwa polskiego, Warszawa 1928.

Błaś A., Między swoboda i prawnym zwiąaniem administracji publicznej, „Prawo” 266. Administracja publiczna w państwie prawa. Księga jubileuszowa dla Profesora Jana Jendrośki, 1999.

Borkowski J., Organizacja zarządzania szkoła wyższq, Wrocław 1978.

Chmielnicki P., Zakłady administracyjne w Polsce. Ustrój wewnętrzny, Warszawa 2008.

Czarnik Z., Posłuszny J., Zakład publiczny, [w:] System Prawa Administracyjnego, t. 6. Podmioty administrujące, red. R. Hauser, Z. Niewiadomski, A. Wróbel, Warszawa 2011.

Duniewska Z., Pewność prawa administracyjnego a sytuacja prawna jednostki - kilka refleksji, [w:] Jednostka wobec władczej ingerencji organów administracji publicznej. Księga jubileuszowa dedykowana Profesor Barbarze Adamiak, red. J. Korczak, K. Sobieralski, Wrocław 2019.

Elżanowski M., Zakład państwowy w polskim prawie administracyjnym, Warszawa 1970.

Fundowicz S., Decentralizacja administracji publicznej w Polsce, Lublin 2005.

Homplewicz J., Polskie prawo szkolne. Zagadnienia podstawowe, Warszawa 1984.

Homplewicz J., Tradycyjne a współczesne instytucje prawa szkolnego. (Studium z zakresu nauki prawa administracyjnego), „Zeszyty Naukowe Uniwersytetu Jagiellońskiego. Prace Prawnicze" 1985, z. 112.

Jendrośka J., Narzędzia badania prawa administracyjnego, „Przegląd Prawa i Administracji” 50, 2002.

Jeżowski A.J., Statut szkoły (od) nowa, „Dyrektor Szkoły” 2017, nr 8.

Jeżowski A.J., Statut konstytucją szkoły, Sopot-Wrocław 2017.

Klonowiecki W., Zakład publiczny w prawie polskim. Studium prawno-administracyjne, Lublin 1933.

Langrod J.S., Z zagadnień prawa zakładowego, „Gazeta Administracji” 1947, nr 5-6.

Lisowski P., Akty normatywne stanowione przez organy zakładów administracyjnych (prawo zakładowe), [w:] Prawo administracyjne, red. J. Boć, Wrocław 2010.

Lisowski P., Prawo zakladowe - in rebus angustis? (wybrane problemy administracyjnoprawne), „Przegląd Prawa i Administracji” 100, 2015, cz. 1.

Lisowski P., Relacje strukturalne w polskim samorzadzie terytorialnym, Wrocław 2013.

Lisowski P., Szkoła samorzadowa jako zaktad administracyjny, Wrocław 1997 (niepubl.).

Lisowski P., Z problematyki postępowania administracyjnego na forum szkoły samorzadowej, [w:] Nauka administracji wobec wyzwań wspótczesnego państwa prawa. Międzynarodowa Konferencja Naukowa Cisna 2-4 czerwca 2002 r., red. J. Łukaszewicz, Rzeszów 2002. 
Niepewność sytuacji prawnej jednostki w prawie administracyjnym, red. A. Błaś, Warszawa 2014.

Ochendowski E., Pojęcie zakładu publicznego, „Studia Iuridica” 32. Współczesne problemy administracji publicznej. Księga poświęcona pamięci Profesora Marka Elżanowskiego, 1996.

Ochendowski E., Zakład administracyjny jako podmiot administracji państwowej, Poznań 1969.

Pewność sytuacji prawnej jednostki w prawie administracyjnym, red. A. Błaś, Warszawa 2012.

Piszko A., Zasady techniki prawodawczej obowiazujace przy opracowywaniu statutu szkoty, przedszkola, jednostki oświatowej, https://sip.lex.pl/\#/publication/470087419/piszko-agata-zasady-techniki-prawodawczej-obowiazujace-przy-opracowywaniu-statutu szkoly...?keyword=Piszko\%20zasady\%20techniki\%20prawodawczej\&cm=SFIRST.

Prawo administracyjne, red. J. Boć, Wrocław 2007.

Prawo administracyjne. Część ogólna, red. J. Blicharz, L. Zacharko, Katowice 2018.

Prawo administracyjne. Pojęcia, instytucje, zasady w teorii i orzecznictwie, red. M. Stahl, Warszawa 2002.

Przybysz P., Sytuacja prawna jednostki w zakładzie oświatowym, [w:] Jednostka wobec działań administracji publicznej. Międzynarodowa Konferencja Naukowa, Olszanica 21-23 maja 2001 r., red. E. Ura, Rzeszów 2001.

Raszewska-Skałecka R., Koncepcja zaktadu administracyjnego w polskiej nauce prawa administracyjnego, „Przegląd Prawa i Administracji” 68, 2005.

Raszewska-Skałecka R., Miejsce statutu i regulaminu zaktadu administracyjnego w systemie źródel prawa. Kwestie wybrane, „Przegląd Prawa i Administracji” 77, 2008.

Raszewska-Skałecka R., Statut i regulamin szkolnego zakładu administracyjnego w świetle obowiazującego systemu źródel prawa, [w:] Nowe prawo o szkolnictwie wyższym a podmiotowość studenta, red. A. Szadok-Bratuń, Wrocław 2007.

Raszewska-Skałecka R., Statut i regulamin zakładu administracyjnego jako źródta prawa, Wrocław 2007.

Raszewska-Skałecka R., Zakres prawnej samodzielności prawotwórczej zakładu administracyjnego, [w:] Administracja publiczna pod rzadami prawa. Księga pamiatkowa z okazji 70-lecia urodzin prof. zw. dra hab. Adama Błasia, red. J. Korczak, Wrocław 2016.

Raszewska-Skałecka R., Zasady konstytucyjne a prawo administracyjne, [w:] Administracja. Prawo administracyjne. Czesść ogólna, red. J. Blicharz, L. Zacharko, Katowice 2018.

Spasowska-Czarny H., Administracyjnoprawny status zakładów publicznych, Lublin 2014.

Starościak J., Studia z teorii prawa administracyjnego, Wrocław 1967.

Ura E., Prawo administracyjne, Warszawa 2015.

Wierzbowski M., Wiktorowska A., Zakład administracyjny, [w:] Prawo administracyjne, red. J. Jagielski, M. Wierzbowski, Warszawa 2019.

Wojtczak B., Czy dyrektor szkoty może przenieść ucznia do klasy równoległej ze względu na „,dobro" tego ucznia?, https://sip.lex.pl/\#/question-and-answer/621863125/czy-dyrektor-szkoly-moze-przeniesc-ucznia-do-klasy-rownoleglej-ze-wzgledu-na-dobro-tego-ucznia?cm=URELATIONS.

Wojtczak B., Czy skreślenie petnoletniego ucznia z listy uczniów jest decyzja administracyjna dyrektora szkoty poprzedzona uchwata rady pedagogicznej?, https://sip.lex.pl/\#/question-and-answer/621973678/czy-skreslenie-z-listy-uczniow-odbywa-sie-w-drodze-uchwaly-rady-pedagogicznej-i-jest-wymagana...?cm=URELATIONS.

Zimmermann J., Prawo administracyjne, Warszawa 2018. 


\title{
Unavoidability of public administration in the scope of administrative establishment's power "removal from the list of students" on the basis of the case-law of administrative courts
}

\begin{abstract}
Summary
The subject matter of procedures in the individual cases of a student, including administrative establishment's power towards a student on school territory and removal from the list of students, affects students' status as so-called users of administrative establishments and is not only relevant and present in administrative law, but still needs the courts' verification and scientific reflection in practice. The procedure for removing a student from the list of students is pending under the provisions of administrative procedural law. A student is removed from the list of students on the basis of the administrative decision and is tantamount to the cessation of the administrative-legal relationship between a student and school. It has to be underlined that a student has the obligation to obey internal regulations which are passed in the school and which are binding on its premises. In particular, these regulations include the school statute. Powers of an administrative establishment (school) towards a student — the so-called "user" — are usually statutorily prescribed and clearly specified in the school statue and in internal school regulations. In the doctrine of administrative law, it is considered that the subordination of a student as a user of the administrative establishment is regulated in education law and his subordination to other acts and orders of the school authorities is defined as an element of the administrative establishment's power. Hence, there is a presence and unavoidability of legal forms of public administration activity in the school and administrative establishment's power influencing the legal situation of a student in the school. Administrative law allows for taking a view on the legal protection of a student and administrative court judiciary allows for taking a view on the legal protection of public subjective rights of an individual - a student in the state ruled by law.
\end{abstract}

Keywords: the right to education, schooling duty and education's duty, education law, administrative establishment, administrative establishment's power, school statute, removal from the list of students. 